\title{
High Commitment Compensation Practices and Employee Turnover Intention: Mediating Role of Job Satisfaction
}

\author{
Mohammad Rabiul Basher Rubel ${ }^{1}$ \\ School of Management, Universiti Sains Malaysia, Penang, Malaysia, 11800 Minden Penang, Malaysia \\ Business Administration Department, Stamford University Bangladesh, Dhaka, Bangladesh
}

Daisy Mui Hung Kee²

School of Management, Universiti Sains Malaysia, Penang, Malaysia, 11800 Minden Penang, Malaysia

\author{
Doi:10.5901/mjss.2015.v6n6s4p321
}

\begin{abstract}
This study explores the relationship between employees' perceptions of high commitment compensation practices (a particular subsystem of High Commitment Human Resource Management Practices) and their turnover intention in the Ready-made garment (RMG) industry of Bangladesh. In addition, the current research examines job satisfaction as mediator in the stated relationship. Partial Least Square Path Modeling in Structural Equation Modeling was employed to test the hypothesized relationship on sample data of 346 operators working in RMG organizations in Bangladesh. A judgmental purposive sampling technique was used to select the sample respondents. Data were collected from the operators about their level of turnover intention, job satisfaction and high commitment compensation practices in 2014. Results demonstrate that employees' perceptions of high commitment compensation practices (HCCPs) reduce the likelihood of their turnover intention. It is found that job satisfaction mediates the above relationship. The findings lead us to believe the importance of understanding the perceptions of HCCPs and related aftereffects at employee level, and to contemplate the effect of job satisfaction in this relationship, if we are to comprehend their influences on organizational performance.
\end{abstract}

Keywords: high commitment compensation practices; job satisfaction; turnover intention, Bangladesh.

\section{Introduction}

Employee turnover not only takes away the talents of the organization, but also hampers the smooth operation of the organization and increases costs as well. Therefore, the aftereffect of such departure is well acknowledged in creating interruptions to the usual processes of an organization and lessening the performance as well (Kacmar, Andrews, Van Rooy, Steilberg, \& Cerrone, 2006; Morrow \& McElroy, 2007). Research in a variety of disciplines has long suggested that minimizing turnover intention has a high potential to minimize actual turnover, since it is considered as the precursor of actual turnover (Liu and Onwuegbuzie 2012; Tekleab, Takeuchi, \& Taylor, 2005).

Employee turnover is also applicable in ready-made garment (RMG) industry setting in Bangladesh which is the largest contributor to the Gross Domestic Product (GDP) of the country (Rubel \& Kee, 2014). RMG industry is not only contributing to the GDP, but also providing a variety of benefits and employment opportunities more than any other sectors (Bhuiyan, 2013). However, this sector observes higher turnover of employees (approximately 25 percent) than any other sectors in Bangladesh (Shamsuzzoha, \& Shumon, 2007). Therefore, local researchers provide their ample suggestions to retain valued employees especially, operators for the development of the RMG sector, both locally and globally because these groups of employees are the prime source of the organizations growth and development (Bhuiyan, 2013).

Drawing on a variety of theoretical perspectives, it is suggested that Human Resource Management (HRM) practices have immense impact on turnover intention in different contexts (Haines, Jelette \& Larose, 2010; Bambacas \& Kulik, 2013; Maneesatitya, \& Fongsuwan, 2014). HRM researchers have shown intense importance within the HRM field concerning how HRM can aid employee attachment with the organization through increasing their level of commitment and thus leading to a growing focus on a new dimension of HRM namely, High Commitment HRM (HCHRM) (GouldWilliams, et al. 2013). HCHRM has been understood as a set of HRM practices that affect employee commitment (Farndale, Hope-Hailey Kelliher, 2011). Intent to remain with the organization likely represents behavioral manifestations of employees' commitment to the organization (Kehoe \& Wright, 2013), thereby suggesting relevance of this outcome to a 
HCHRM approach. This study focuses here on a single dimension within HCHRM: high commitment compensation practices (HCCPs). HCCPs include commitment focused rewards and benefits which are assumed to engender employee attachment through meeting their job satisfaction and thereby, reducing turnover intention for a longer relationship with the organization.

To provide a comprehensive view of how HCCPs might influence turnover intention, the current study followed the suggestions of Haines et al. (2010), who posited the effect of specific HRM practice on employee turnover of the Canadian nongovernmental sector. They consider specific HRM practice because bundle HRM practices explain insufficient information about the detailed impact of any single dimension of HRM practice. Therefore, in line with this, the present focus is to highlight the impact of single component of HCHRM practices that is HCCPs considering its different sub-dimensions (rewards and benefits) in relation to individual employee outcome specifically, their turnover intention. Thus, this study presents the argument that for HCCPs to have the consequence of reducing turnover intention, this depends on the degree to which employees understand this practice to increase their job satisfaction as well. Job satisfaction is employed here as a mediator through which HCCPs can lead to the reduction of employee thinking of quitting (see Figure 1).

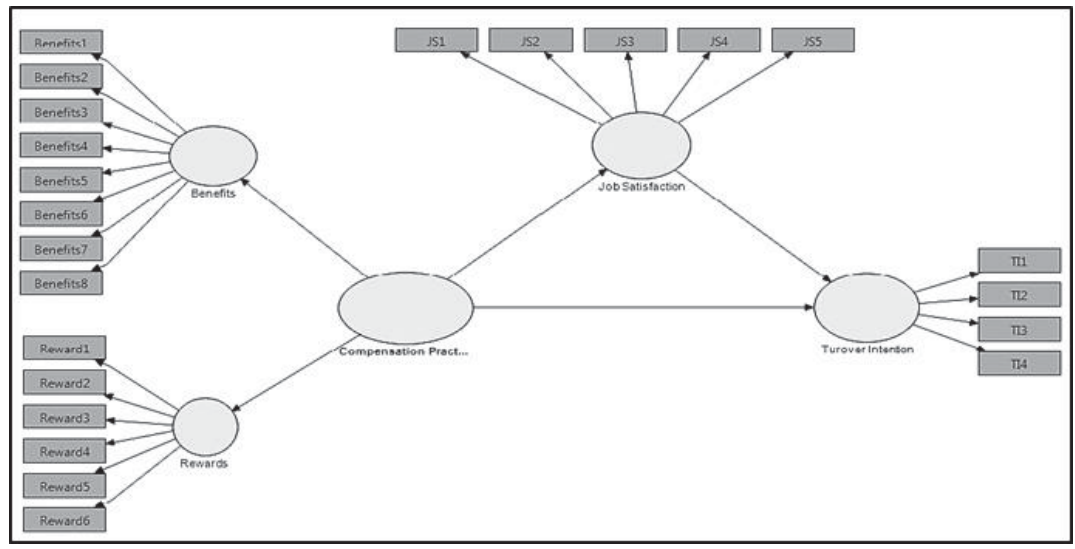

Figure 1: Conceptual Framework

Our study draws on work that suggests that the specific or single dimension of HRM practices, more specifically a sub system of HCHRM practices, in an elaborative aspect, consists of its different components. Furthermore, this study assumes to contribute from the methodological point of view as well. This study presents the idea on the higher order constructs of the individual dimension of HRM practices based on their respective components in the SEM-PLS. In the earlier research there is no study found employing higher order constructs of individual dimension of HRM practices in PLS. The present study aims to fulfill the stated research gap. Thus, this study extends the existing literature by reconceptualizing different dimensions of compensation practice as HCCPS as a hierarchical reflective construct and scrutinizing its direct effect on turnover intention through the indirect effect of job satisfaction.

\section{Literature Review}

\subsection{High Commitment Compensation Practices}

As commitment is an important outcome of HRM, HRM researchers group certain HRM practices to support a desire for high commitment and name them HCHRM (Juhdi, Pa'wan, \& Hansaram, 2013). Compensation is widely acknowledged in HCHRM practices while assessing both the attitudinal and behavioral outcomes of employees through HCHRM (GouldWilliams, et al. 2013; Juhdi et al., 2013). As such, HCCP can be assumed as a commitment enhancing HRM practice. In the area of RMG sector in Bangladesh, compensation is considered the most vital aspect of management of the employees (Rubel \& Kee, 2014). Sarker and Afroze (2014) revealed that inadequate compensation is the main cause of the operator's dissatisfaction that provokes other negative consequences such as, absenteeism, lateness and strike in this sector. Therefore, local researchers proclaimed that organization need to design and execute a suitable employee 
perceived compensation practices which can enhance commitment, promote satisfaction, and pursue the employees to continue with the organization in the long term.

Compensation refers to the benefits employees obtain from their organization to compensate the loss incurred by them in sacrificing their resources (time, effort and knowledge) for the organization's gain. Milkovich and Bloom (1998) define compensation as all forms of financial reward and tangible benefits that an employee receives while working in the organization. Dessler (2009, p. 250) defines compensation as "all forms of pay or rewards going to employees and arising from their employment". Further, Bhatia (2010, p. 1) defines "compensation is the systematic approach to provide monetary values to employees in exchange for work performed". Joseph (2009) defines compensation representing both the compensation/rewards (intrinsic and extrinsic) and all other necessary required benefits employees receive for performing their jobs. The following table gives a clear picture about how distinguished scholars have used different dimensions to categorize compensation.

Table 1: Compensation and its different Dimensions

\begin{tabular}{|c|c|}
\hline Authors & Different Dimensions of Compensation \\
\hline Whitney (1988) & $\begin{array}{l}\text { Direct payments (wages, salaries, bonuses, commission, and incentives) and indirect } \\
\text { payments (employers-paid insurance and vacations) }\end{array}$ \\
\hline $\begin{array}{l}\text { Fisher, Schoenfeldt, and Shaw } \\
\text { (1999) }\end{array}$ & $\begin{array}{l}\text { Reward (direct financing such as salary, bonuses, commission) and benefits (indirect, such } \\
\text { as, paid-leave, medical allowance, vacation, child care facilities). }\end{array}$ \\
\hline Mathis and Jackson (2000) & $\begin{array}{l}\text { Rewards (monetary and non-monetary) all benefits (vacation, leave facilities, recreation } \\
\text { opportunities, health insurance, transport facilities) }\end{array}$ \\
\hline Chiu, Luk and Tang (2002) & Basic and various payment Pension, Low interest lone, Insurance, Leave and Allowances \\
\hline Murphy and Williams (2005) & $\begin{array}{l}\text { Monetary (base salary, performance bonus, fringe benefits, retirement plan and equity } \\
\text { interests) and non-monetary (quality of working condition, transport facilities, child care } \\
\text { facilities, vacation, job autonomy, job responsibility and community association) }\end{array}$ \\
\hline Dessler (2009) & $\begin{array}{l}\text { Direct financial compensation (wages, salaries, rewards, commission and bonuses) indirect } \\
\text { financial compensation (insurance, vacation facilities, leave facilities medical facilities). }\end{array}$ \\
\hline Joseph (2009) & $\begin{array}{l}\text { Reward (intrinsic such as, job character components and extrinsic such as, core } \\
\text { compensation elements) and benefits (protection program, health and safety benefits, paid } \\
\text { leave facilities, pay for time when they are not working, e.g., vacation, medical leave, such as, } \\
\text { maternity leave, paternity leave, family benefits, such as child care facilities, elder care } \\
\text { facilities). }\end{array}$ \\
\hline Bhatia (2010) & $\begin{array}{l}\text { Direct compensation or reward (base salary, wages, overtime payments, holiday premium, } \\
\text { bonuses and profit sharing) indirect compensation or benefits (health insurance, retirement } \\
\text { benefits pay for vacation or illness, welfare and social security, elder care, child care flexible } \\
\text { working schedules, subsidized housing) }\end{array}$ \\
\hline Authors & Dimensions considered in Previous Empirical Research \\
\hline Hoque et al. (2013) & $\begin{array}{l}\text { Consider direct extrinsic compensation, indirect extrinsic compensation and indirect } \\
\text { compensation are the components of compensation package }\end{array}$ \\
\hline Cao, Chen and Song (2013) & $\begin{array}{l}\text { Incorporated monetary external remuneration, non-monetary external remuneration and } \\
\text { inherent remuneration are the components of total reward practice. }\end{array}$ \\
\hline Giancola (2009) & $\begin{array}{l}\text { Simplified compensation as remuneration, welfare, work-life balance, performancel } \\
\text { appreciated and development or career opportunity. }\end{array}$ \\
\hline $\begin{array}{l}\text { Balkin and Gomez-Mejai } \\
(1990)\end{array}$ & $\begin{array}{l}\text { Contemplate compensation practices as pay design and explain it by incorporating three } \\
\text { dimensions such as, Salary, Benefits and pay incentives. }\end{array}$ \\
\hline Sturman (2001) & Pay, benefits, financial incentives and non-financial compensation \\
\hline Igalens \& Roussel (1999) & Contemplate compensation by employing fixed pay, flexible pay and benefits. \\
\hline
\end{tabular}

Drawing on the previous literature, we consider rewards and benefits are the two separate dimensions of compensation (Mathis \& Jackson 2000; Joseph, 2009) which is further considered as HCCP: a sub-system within HCHRM practices.

\subsection{Specifying HCCP as a Higher Oder Reflective Model}

Higher order constructs or multidimensional constructs comprise of at least two dimension where each dimension describes certain percentage of the overall latent variable (Wetzels, Odekerken-Schroder, \& Van Oppen, 2009). In higher order construct, the measurement model or outer model is based on the connection between indicators and latent variables (Henseler, Ringle, \& Sinkovics, 2009), which can be set in two different types, such as, reflective and formative. 
Based on the previous literature support on compensation practice, the current study specify HCCP as a higher order model which is incorporated by two reflective constructs such as rewards and benefits (Figure $2 a \& b$ ). Furthermore, most of the constructs are adapted from earlier literature that have experienced a rigorous scale development process which emphasize on the inter-correlations among items, common variance, unidimensionality and internal consistency whereby all these reflect the characteristics for reflective model measurement (Diamantopoulos \& Siguaw, 2006).

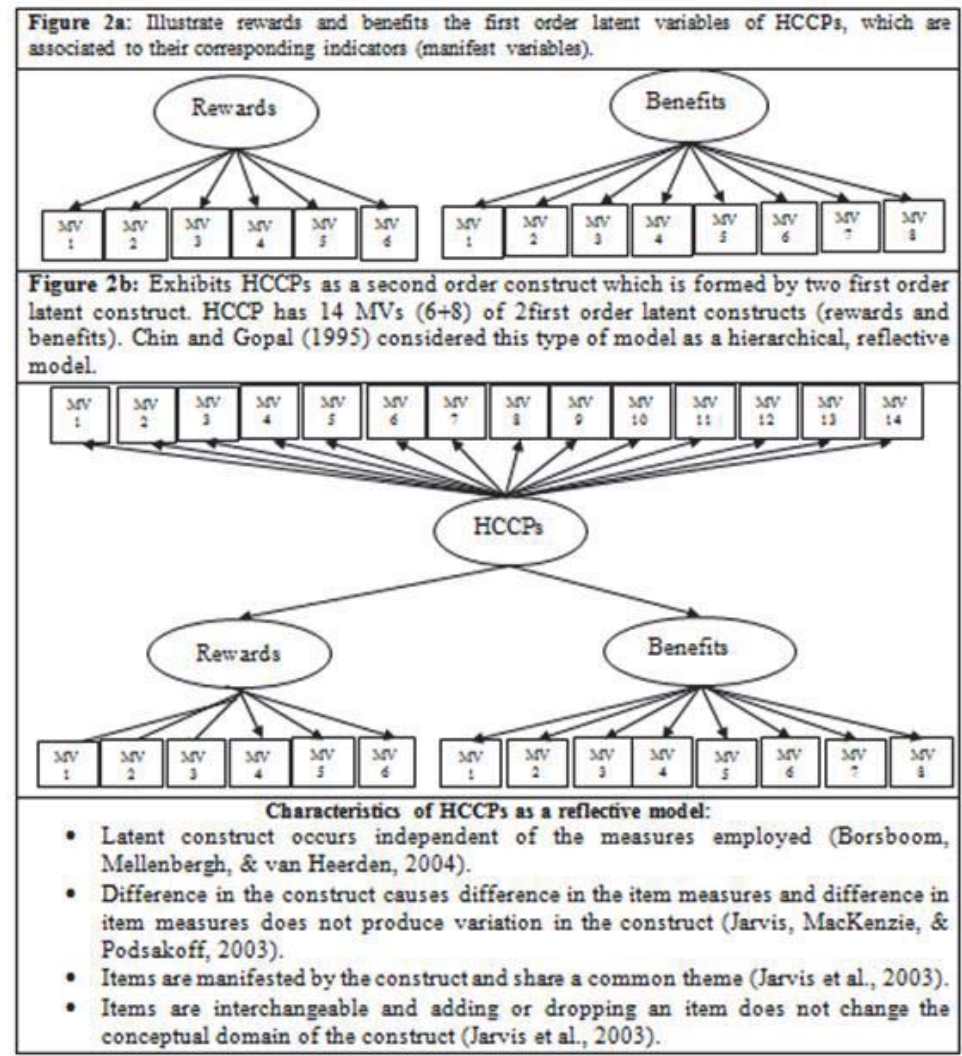

Figure 2a \& b: High Commitment Compensation Practice in hierarchical reflective Model

\subsection{Hypotheses Development}

\subsubsection{Compensation practices and turnover intention}

In HRM literature, researchers confirmed the link between compensation as a dimension of HRM, and employee turnover intention (Lockwood, 2007; Juhdi et al., 2013). Allen, Shore and Griffeth (2003) indicated the significant negative relationship between rewards, an HRM practice, and employee turnover intention. Nadiri and Tanova (2010) have asserted that rational distribution of pay and rewards have impact on the employees' turnover intentions. Furthermore, Carraher and Buckley (2008) found the significant negative relationship between benefits and employee's search for a new job and quitting from the organization. Armstrong and Murlis (2007) revealed that high pay influences employees' stay with the organization for a long time. As such, employees who experience appropriately rewarded for their contribution to the organization, they will have greater interest to stay with the organization. Therefore, based on the literature support, it can be hypothesized as follows:

Hypothesis 1: The higher the level of Compensation practice the lower the level of employee turnover intention. 


\subsubsection{Compensation practices and job satisfaction}

Compensation is noticed as an important predictor of employee job satisfaction in the organization (Mudor \& Tooksoon, 2011). A study conducted by Chuang, Yin \& Dellmann-Jenkins (2009) on hotel employees' job satisfaction discovered the positive influence of compensation on job satisfaction. Hofmans, Gieter and Pepermans (2013) have asserted that financial reward has more capacity than psychological reward to satisfy all types of employees. Spagnoli, Caetano and Santos (2012) have established a consistent positive influence of reward on job satisfaction. Islam and Siengthai (2009) claimed that fringe benefits in compensation help to minimize the employees' level of dissatisfaction. Prior literature gives evidences of positive relationship between different dimensions of compensation and job satisfaction. Since compensation is a significant determinant of job satisfaction of employees, the notion helps to construct the following hypothesis:

Hypothesis 2: The higher the level of compensation practice the higher the level of employee job satisfaction.

\subsubsection{Job satisfaction and turnover intention}

Turnover intention is one of the important expressions of employee dissatisfaction (Wang, Yang, \& Wang, 2012). Aydogdu and Asikgil (2011) found a strong negative relationship between job satisfaction and turnover and stated that understanding overall job satisfaction is the main predictor of analyzing employee turnover intention. Research on job satisfaction and turnover intention found similar negative results among different employee groups across the countries such as, IS professionals in India (Lacity, Iyer and Pudramuniyaiah, 2008); Spanish repatriate managers (Vidal, Valle, and Aragón, 2007); Pakistani doctors (Malik, Gomez, Ahmad, and Saif, 2010) and, public and private organizations in Taiwan (Wang, et al., 2012). Kabungaidze, Mahlatshana and Ngirande (2013) ascertained a negative association between job satisfaction and quitting intention among teachers. Hence, earlier research findings aid to develop following hypothesis.

Hypotheses 3: The higher the level of job satisfaction the lower the level of employee turnover intention.

\subsubsection{Job satisfaction as mediator}

Researchers found the mediating influence of job satisfaction between internal service quality and organizational performance (Wang, 2011); time pressure and health outcomes (Silla \& Gamero, 2014) and core self-evaluation and burnout (Peng et al., 2014). In analyzing turnover intention, researchers also found the role of job satisfaction as mediator (Sousa-Poza, Henneberger, 2004; Nawab \& Bhatti, 2011). Job satisfaction mediated the effect of pay and promotion on turnover intentions (Joseph, $\mathrm{Ng}, \mathrm{Koh}, \&$ Ang, 2007). Choudhury and Mishra (2011) found job satisfaction as partial mediator in the effect of competitive compensation, career advancement opportunity, challenging work environment and learning culture on turnover intention of talented workforce in business process outsourcing organization in India. Therefore, these study findings help to constitute the following hypothesis:

Hypothesis 4: Job satisfaction intervenes between compensation practice and turnover intention relationship.

\section{Methodology}

\subsection{Sample}

The study employed cross-sectional data collected in 2014 from Dhaka, Bangladesh. Since more than 65 percent RMG organizations were in Dhaka and more than 70 percent operators were working in this region (BGMEA, 2012), Dhaka was considered as study location. The sample was selected purposively from operators working in different RMG organizations. The researchers considered judgmental sampling for choosing the respondents. The current study received 405 questionnaires from the total 800 distributed yielding a response rate of $40.5 \%$. Fifty nine (59) was removed due to unfilled questionnaire. Therefore, the current study was found 346 questionnaires completed for data analysis. For a sufficient number of samples, Sekaran and Bougie (2010) suggested taking 10 times or more as large as the variables in the study. Moreover, Reinartz, Haenlein and Henseler (2009) also postulated 100 cases are sufficient to achieve acceptable levels of statistical power in PLS-SEM. In the context of Bangladesh, earlier researchers found a $29 \%$ response rate (Rubel and Kee 2015). Thus, 346 sample size is deemed sufficient for data analysis in PLS-SEM in present study. 


\subsection{Measurement}

The items of compensation practice of this study were adapted from existing recognized scales. Two dimensions (reward and benefits) were considered for measuring employee perception of HCCP. In total fourteen (14) items were considered for compensation practices where 6 for reward and 8 for benefits. All items for both dimensions were adapted from Islam and Siengthai (2009) and Abeysekera (2007). Scale validity reported ranges from 0.80 to 0.91 . A unidimensional five items of job satisfaction measurement was adapted from Judge and Klinger (2008) with a reliability of 0.80 . All items of HCCP and job satisfaction were measured by using five point Likert scales from 1 (Strongly disagree) to 5 (strongly agree). Finally, turnover intention was examined based on Dailey and Kirk's (1992) scale which was composed of four (4) items that had demonstrated high reliability (0.89). All the items of turnover intention were measured by seven (7) point Likert scale that ranges from 1 (strongly disagree) to 7 (strongly agree).

\subsection{Statistical analysis}

Partial least square path modeling (PLS-PM) was employed to assess both the measurement and structural model. Collected data were input into the Statistical Package for Social Science (SPSS) version 21 to assess the descriptive analysis of the variables and the respondent's profile. Table 2 presents the demographic profile of the respondents.

Table 2: Demographic Information about the respondents

\begin{tabular}{lcc}
\hline Demographic Information & Respondents Number (N= 346) & Percentage (\%) \\
\hline Gender: & 155 & \\
Male & 191 & 44.8 \\
Female & & 55.2 \\
Age: & 149 & \\
20 - 24 years & 124 & 43.1 \\
25 - 29 years & 46 & 36.1 \\
30 - 34 years & 26 & 13.3 \\
35 - 39 years & & 7.5 \\
Religion & 219 & \\
Muslim & 88 & 63.3 \\
Hindu & 23 & 25.4 \\
Christian & 16 & 6.6 \\
Buddhists & & 4.6 \\
Marital Status & 155 & \\
Single & 179 & 44.8 \\
Married & 12 & 51.7 \\
Divorced & & 3.5 \\
Income & 115 & \\
Bellow Taka 5000 & 176 & 33.2 \\
Taka 5000 - to 10000 & 55 & 50.9 \\
Take 10000 - 15000 & & 15.9 \\
Industry Experience & 112 & \\
1 - 4 years & 169 & 32.4 \\
5 - 9 years & 52 & 44.8 \\
10 - 14 years & 13 & 15.0 \\
14 years above & & 3.8 \\
\hline
\end{tabular}

\section{Results and Discussion}

\subsection{Measurement Model}

A confirmatory factor analysis (CFA) was conducted to ensure the reliability, convergent validity and discriminate validity (table 3). Beginning of the analysis the current study investigated the respective loading and cross loading to assess if there is any problem with any particular item. This study employed a cutoff value for loading at point 0.6 as significant (Hair, Ringle, \& Sarstedt, 2011). According to Chin (2010), the value of AVEs and the composite reliability are significant at 0.5 and 0.7 respectively. This study shows that the lowest CR is 0.850 for job satisfaction and AVE is 0.503 reported for reward. 
Table 3: Outcome of the measurement model

\begin{tabular}{llccc}
\hline Construct & Measurement items & Loadings & AVE & CR \\
\hline Benefits & Benefits1 & 0.654 & 0.728 & 0.900 \\
& Benefits2 & 0.819 & & \\
& Benefits3 & 0.777 & & \\
& Benefits4 & 0.724 & & \\
& Benefits5 & 0.634 & & \\
& Benefits6 & 0.715 & & \\
& Benefits7 & 0.734 & & \\
Job & Benefits8 & 0.750 & & 0.850 \\
Satisfaction & JS1 & 0.768 & 0.729 & 0 \\
& JS2 & 0.706 & & \\
& JS3 & 0.744 & & \\
Rewards & JS4 & 0.670 & & \\
& JS5 & 0.753 & & \\
& Reward1 & 0.747 & 0.714 & 0.862 \\
& Reward2 & 0.405 & & \\
& Reward3 & 0.700 & & \\
& Reward4 & 0.493 & & \\
Turnover & Reward5 & 0.750 & & \\
Intention & Reward6 & 0.749 & & \\
& TI1 & 0.698 & 0.828 & 0.894 \\
& TI2 & 0.825 & & \\
& TI3 & 0.886 & & \\
\hline
\end{tabular}

Again, for the discriminant validity (Table 4) this study calculated the square root of AVEs and found that the values of all the diagonal numbers are much greater than the corresponding off-diagonal ones. Thus, the measurement model fulfills its criteria to be accepted (Chin, 2010). Further Stone-Geisser $\mathrm{Q}^{2}$ was computed for evaluating the predictive relevance. Chin (2010) advocated that the value of commonality (Com) and redundancy (Red) in $\mathrm{Q}^{2}$ must be higher than zero for instance, job satisfaction (Red: 0.064, Com: 0.551), turnover intention (Red: 0.80, Com: 0.689).

Table 4: Discriminant validity of the constructs

\begin{tabular}{ccccc}
\hline & BEN & JS & RWD & TI \\
\hline BEN & $\mathbf{0 . 7 2 8}$ & & & \\
JS & 0.325 & $\mathbf{0 . 7 2 9}$ & & \\
RWD & 0.452 & 0.287 & $\mathbf{0 . 7 1 4}$ & $\mathbf{0 . 8 2 4}$ \\
TI & -0.268 & -0.274 & -0.279 & 4.31 \\
Mean & 3.45 & 4.03 & 3.72 & 1.23 \\
S.D. & 0.78 & 0.61 & 0.62 &
\end{tabular}

Note: Diagonals (in bold) represent the squared root of AVE while the off diagonal denote the correlations of the dimensions.

$\mathrm{BEN}=$ Benefits, $\mathrm{RWD}=$ Reward, $\mathrm{CP}=$ Compensation, $\mathrm{JS}=$ job satisfaction, $\mathrm{Tl}=$ Turnover intention.

\subsection{The Hierarchical HCCPs model}

In evaluating the higher-order constructs, we used the technique of repetitive indicators. In assessing the second order construct, Chin, Marcolin and Newsted (2003) propose the product indicator approach where a second order factor is directly computed by examining variable for all the first order factors. As described previously, the current study denotes HCCPs as a second order construct, which is formed by 2 first order reflective constructs ( 6 items for rewards and 8 items for benefits) embodying 14 items. Hulland (1999) suggested that the correlations between the latent constructs in the first order determine whether the second order construct is correctly demonstrated as reflective latent construct. This study shows significant correlation among all the items at $p<0.01 .53 .7 \%$ and $85.9 \%$ variance in HCCP are explained by rewards and benefits respectively (table 5 ). The path coefficients from HCCP to rewards and benefits were significant at $p$ $<0.01$. The CR and AVE of HCCP were 0.820 and 0.689 respectively. 
Table 5: Hierarchical HCCPS

\begin{tabular}{cc}
\hline & $(\mathrm{CR}=0.820, \mathrm{AVE}=0.689)$ \\
\hline Benefits & Rewards \\
$\mathrm{R}^{2}=0.537$ & $\mathrm{R}^{2}=0.859$ \\
$\beta=0.733$ & $\beta=0.927$ \\
$\mathrm{P}<0.01$ & $\mathrm{P}<0.01$ \\
\hline
\end{tabular}

\subsection{Structural model}

In order to assess the hypothetical relationship among the variables we develop a structural model in which HCCP (reward and benefits) is modeled as exogenous latent variable influencing both job satisfaction and employee turnover intention. As shown in Table 6 and Figure 3, the path from compensation practices to turnover intention and compensation practice to job satisfaction was found statistically significant and the values are $(\beta=-0.220, p<0.01)$ and $(\beta=0.349, p<0.01)$ respectively. Moreover, the other paths from job satisfaction to turnover intention $(\beta=-0.197, p<$ 0.01 ) also showed the significant negative relationship.

Furthermore, this study also assesses the indirect influence of job satisfaction between HCCP and employee quitting intention. In this regard, Preacher and Hayes (2008) assessment of the mediation effect for structural equation model (SEM) with the bootstrap test was employed and revealed that the mediation effect is believed to be significant while the indirect relationship between independent and dependent variables come out as significant (Table 6). It is indispensable to evaluate both the upper limit and lower limit value of the bootstrap confidence interval. Preacher and Hayes (2008) referred that if the upper and lower limit value does not include 0 (zero) in between representing, there is mediation. In this study job satisfaction satisfy the criteria and demonstrates a significant mediating effect on the relation between $\mathrm{HCCP}$ and turnover intention (95\% LL= -0.108, 95\% UL=-0.030).

Table 6: Result of partial squares path analysis

\begin{tabular}{|c|c|c|c|}
\hline Direct Path & Std. Beta & $\mathrm{t}$-Value & Decision \\
\hline Compensation Practices > Job Satisfaction & 0.349 & $7.012^{\star \star}$ & Supported \\
\hline Compensation Practices > Turnover Intention & -0.220 & $4.352^{* *}$ & Supported \\
\hline Job Satisfaction > Turnover Intention & -0.197 & $4.348^{* *}$ & Supported \\
\hline \multicolumn{4}{|c|}{ Note: ${ }^{*} p<0.01,{ }^{*} p<0.05$, (analyze the direct relationship based on one-tailed) } \\
\hline Indirect Path (Mediating effect) & Std. Beta & t-Value & Decision \\
\hline Compensation Practices > Job Satisfaction > Turnover Intention & -0.069 & $3.775^{\star \star}$ & Supported \\
\hline
\end{tabular}

\section{Discussion}

This paper aimed to look at the relationship between employee perceptions of HCCP and their turnover intention from the organization. In addition, the study was intended to investigate the mechanism by which the perception of HCCP affect particular employee attitude of job satisfaction and consequential turnover intention. All the hypotheses of this study acknowledged significant support. The results of the study found a strong negative association between employee perceptions of HCCP and turnover intention. The findings of the study suggest that greater emphasis on employee perceived HCCP provides a better attachment of employee with the organization through lowering turnover intention. In the context of Bangladesh, research on HRM in different filed also found the negative relation of compensation with turnover intention and turnover in which compensation was found having a strong capacity to create bondage of employees with the organization by lowering their turnover intention (Sarker \& Afroze, 2014). Therefore, it is evident that compensation and its different dimensions perceived by employees are influential to determine their continuity with the organization.

The other findings of the study regarding employee perceived HCCP and job satisfaction showed a positive significant result, which is in line with previous findings where compensation was considered a dimension of HRM and a predictor of job satisfaction (Gould-Williams, et al. 2013). The findings of this study elucidate that commitment focused compensation preferred by employees are more likely to generate high level of job satisfaction among employees. Thus, organizations should recognize HCCP as an important satisfier of employees. Furthermore, another result of the study revealed a negative relationship between job satisfaction and employee turnover intention which support earlier studies 
as well (Aydogdu \& Asikgil, 2011; Wang et al., 2012). Hence, organization needs to be concerned for making the employee satisfied as satisfied employees are more devoted to the organization for attaining the goal of the organization.

The present study also supported the link between HCCP and employee turnover intention mediated by perception of job satisfaction. This supports the notion of the significance of job satisfaction as attitude in explaining employee behaviors (Joseph, et al., 2007). Therefore, the result of the study can convey the message that employee perceived HCCP can minimize their turnover intention through making them more satisfied in the organization. Thus, it can be recommended that management of the organization should focus on employee perceived HCCP not only as commitment enhancer but also as satisfier, because HCCP together with job satisfaction reduces turnover intention more among the employees through making them satisfied in the organization.

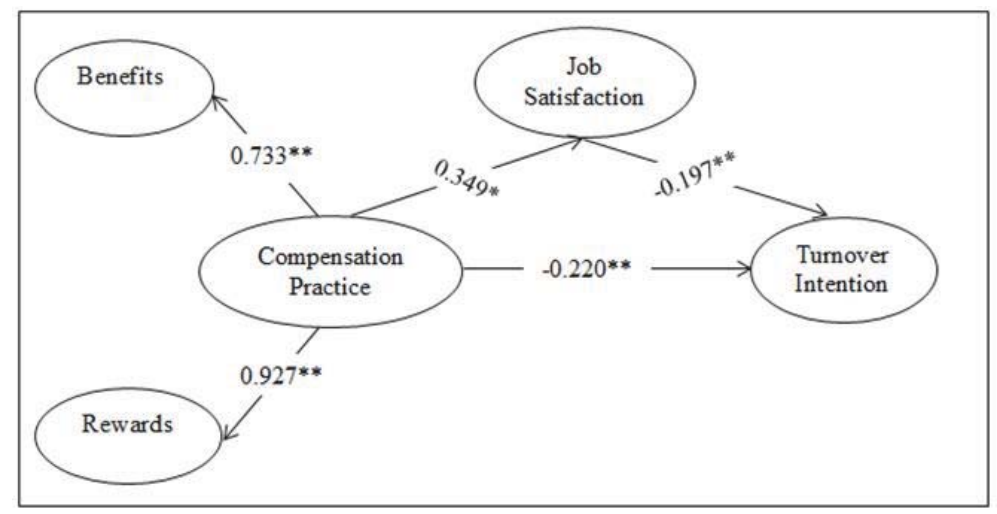

Figure 3: Structural Model

Thus, this study has threefold key findings. First, at a theoretical stage, the current research adds how specific HRM practice results in HRM outcomes. HCCP promotes job satisfaction and lowers quitting intention of employees in the organization. Thus, HCCP with its dimensions helps to achieve the position of the specific/individual dimension of HCHRM practices in HRM literature that support the argument that studying individual HRM practice is crucial (Haines, et al., 2010). Second, this finding supports the concept that proper compensation satisfies as well as retains employees and deprivation of proper compensation makes employees dissatisfied and leaving employees. Third, a particular finding of the study elucidates the mechanism of HRM influence on HR outcome workings: HCCP reduces employee turnover intention through job satisfaction. In our exploration of the mechanism explaining about the HRM practices and the employee outcome in the organization, we have seen that how the dimensions of specific HCHRM practice that is HCCP engender the feeling of employee satisfaction to reduce turnover intention. Overall, the findings of the examination of HCCP with its dimensions will give a new insight to the researchers in focusing other dimensions of HCHRM practices with their respective category.

\section{Limitations and Further Research}

The current research findings have numerous suggestions for future research few of which connect with the limitations of this study. In this study, only operators of RMG organizations in Dhaka city were investigated. The study data were collected only from the individual employee level. Thus, the generalizability of the study findings is rather partial and results could be used with more cautions. The study findings will be more reliable if future researchers collect data from both employer and employee level to reconcile their respective perceptions on HCCP and its outcomes. Upcoming study in this arena can examine how other individual HRM practices with their particular dimensions may play the role on employee attitudes and behavior. Moreover, we propose future researchers and practitioners to investigate the higher order constructs of specific dimensions of HRM practices depending on the different sub-dimensions explored in the previous literature and their applicability in the organization. 


\section{Conclusion}

The objective of this research was to assess both direct and indirect effect of HCCP through job satisfaction on turnover intention of RMG operators in Bangladesh. The most prevailing observation from the respondents is that commitment oriented compensation has the possibility to lessen their turnover intention directly as well as indirectly through job satisfaction. From practical standpoint, the new experience acquired from perceiving the association between specific HCHRM practice and employee attitude may be useful in understanding the specific effect of single HRM practice on the operating level employees in labor intensive organizations. Our findings suggest important implications for and managers. For managers faced with high turnover, it is important to anticipate how compensation decisions will influence employees' commitment and satisfaction and in turn affecting their stay with their respective organizations. The study undertaken here directs us to acknowledge and implement the process of observing actual employee perceptions of HCCP and its related outcomes on individual employee if we are to realize HRM impact on both employee and firm performance.

\section{References}

Abeysekera, R. (2007). The impact of human resource management practices on marketing executive turnover of leasing companies in Sri Lanka. Contemporary Management Research, 3(3), 233-252.

Allen, D. G., Shore, L. M., \& Griffeth, R. W. (2003). The role of perceived organizational support and supportive human resource practices in the turnover process. Journal of management, 29(1), 99-118.

Armstrong, M., \& Murlis, H. (2007). Reward management: a handbook of remuneration strategy and practice: Kogan Page Publishers.

Aydogdu, S., \& Asikgil, B. (2011). An empirical study of the relationship among job satisfaction, organizational commitment and turnover intention. International Review of Management and Marketing, 1(3), 43-53.

Balkin, D. B., \& Gomez-Mejia, L. R. (1990). Matching compensation and organizational strategies. Strategic Management Journal, 11(2), 153-169.

Bambacas, M., \& Kulik, T. C. I. (2013). Job embeddedness in China: how HR practices impact turnover intentions. The International Journal of Human Resource Management, 24(10), 1933-1952.

Bhatia, K. (2010). Compensation Management: Himalaya Publishing House.

Bhuiyan, M. I. (2013). Reasonable wages for workers to eliminate unrest in Bangladesh's ready-made garments (RMG) sector. Fowler Street, U. S. A.: Bangladesh Development Research Center (BDRC).

Borsboom, D., Mellenbergh, G. J., \& van Heerden, J. (2004). The concept of validity. Psychological review, 111(4), 1061-1071.

Cao, Z., Chen, J., \& Song, Y. (2013). Does Total Rewards Reduce the Core Employees' Turnover Intention? International Journal of Business and Management, 8(20), 62-75.

Carraher, S. M., \& Buckley, M. R. (2008). Attitudes towards benefits and behavioral intentions and their relationship to Absenteeism, Performance, and Turnover among nurses. Journal of Applied Management \& Entrepreneurship, 4(2), 89-109.

Chin, W. W. (2010), How to write up and report PLS analyses. In In: J. E. Gentle Wkhym (Ed.), Handbook of partial least squares (pp. 655-690): Springer.

Chin, W. W., \& Gopal, A. (1995). Adoption intention in GSS: relative importance of beliefs. ACM SigMIS Database, 26(2-3), 42-64.

Chin, W. W., Marcolin, B. L., \& Newsted, P. R. (2003). A partial least squares latent variable modeling approach for measuring interaction effects: Results from a Monte Carlo simulation study and an electronic-mail emotion/adoption study. Information systems research, 14(2), 189-217.

Choudhury, D., \& Mishra, S. (2011). Compensation-satisfaction correlation at workplace: A study on BPOs at Orissa. International Journal of Business and Management Tomorrow, 1(1), 1-15.

Chuang, N., Yin, D., \& Dellmann-Jenkins, M. (2009). Intrinsic and extrinsic factors impacting casino hotel chefs' job satisfaction. International Journal of Contemporary Hospitality Management, 21(3), 323-340.

Chiu, R. K., Luk, V. W. M., \& Tang, T. L. P. (2002). Retaining and motivating employees: Compensation preferences in Hong Kong and China. Personnel Review, 31(4), 402-431.

Daileyl, R. C., \& Kirk, D. J. (1992). Distributive and procedural justice as antecedents of job dissatisfaction and intent to turnover. Human Relations, 45(3), 305-317.

Dessler, G. (2009). Fundamentals of human resource management: Pearson Higher Ed.

Diamantopoulos, A., \& Siguaw, J. A. (2006). Formative versus reflective indicators in organizational measure development: a comparison and empirical illustration. British Journal of Management, 17(4), 263-282.

Farndale, E., Hope-Hailey, V., \& Kelliher, C. (2011). High commitment performance management: the roles of justice and trust. Personnel Review, 40(1), 5-23.

Fisher, C. D., Schoenfeldt, L. F., \& Shaw, J. B. (1999). Human resource management (4th ed.). Boston: Houghton Mifflin Company.

Giancola, F. L. (2009). Is Total Rewards a Passing Fad? Compensation \& Benefits Review, 41(4), 29-35.

Gould-Williams, J. S., Bottomley, P., Redman, T., Snape, E., Bishop, D. J., Limpantgul, T., \& Mostafa, A. M. S. (2013). Civic duty and employee outcomes: Do high commitment human resource practices and work overload matter? Public Administration, In press.

Haines, V. Y., Jalette, P., \& Larose, K. (2010). The influence of human resource management practices on employee voluntary turnover rates in the Canadian non- governmental sector. Industrial and Labor Relations Review, 63(2), 228-246. 
Hair, J. F., Ringle, C. M., \& Sarstedt, M. (2011). PLS-SEM: Indeed a silver bullet. The Journal of Marketing Theory and Practice, 19(2), $139-152$

Hoque, K. E., Zohora, M. F., Mishra, P. K., Leng, C. H., \& Darusalam, G. (2013). Impact of compensation package on job attrition: a study on teaching professionals. Life Science Journal, 10(2), 2528-2534.

Henseler, J., Ringle, C. M., \& Sinkovics, R. R. (2009). The Use of Partial Least Square Path Modeling in International Marketing.: Emerald Group Publishing Limited.

Hofmans, J., De Gieter, S., \& Pepermans, R. (2013). Individual differences in the relationship between satisfaction with job rewards and job satisfaction. Journal of Vocational Behavior, 82(1), 1-9.

Hulland, J. (1999). Use of partial least squares (PLS) in strategic management research: a review of four recent studies. Strategic management journal, 20(2), 195-204.

Igalens, J., \& Roussel, P. (1999). A study of the relationships between compensation package, work motivation and job satisfaction. Journal of Organizational Behavior, 20(7), 1003-1025.

Islam, M. Z., \& Siengthai, S. (2009). Quality of work life and organizational performance: Empirical evidence from Dhaka Export Processing Zone. Paper presented at the ILO Conference on 'Regulating for Decent Work', held at the International Labour Office, Geneva.

Jarvis, C. B., MacKenzie, S. B., \& Podsakoff, P. M. (2003). A critical review of construct indicators and measurement model misspecification in marketing and consumer research. Journal of consumer research, 30(2), 199-218.

Joseph, M. (2009). Strategic Compensation: A human resource management approach (3rd ed.). India: Pearson education.

Joseph, D., Ng, K. Y., Koh, C., \& Ang, S. (2007). Turnover of information technology professionals: a narrative review, meta-analytic structural equation modeling, and model development. MIS Quarterly, 31(3), 547-577.

Judge, T. A., \& Klinger, R. (2008). Job satisfaction: Subjective well-being at work. In M. Eid \& J. Larsen (Eds.), The science of subjective well-being (pp. 393-413). London: The Guilford Press.

Juhdi, N., Pa'wan, F., \& Hansaram, R. M. K. (2013). HR practices and turnover intention: the mediating roles of organizational commitment and organizational engagement in a selected region in Malaysia. The International Journal of Human Resource Management, 24(15), 3002-3019.

Kabungaidze, T., Mahlatshana, N., \& Ngirande, H. (2013). The impact of job satisfaction and some demographic variables on employee turnover intentions. International Journal of Business Administration, 4(1), 53-65.

Kacmar, K. M., Andrews, M. C., Van Rooy, D. L., Steilberg, R. C., \& Cerrone, S. (2006). Sure everyone can be replaced... but at what cost? Turnover as a predictor of unit-level performance. Academy of Management Journal, 49(1), 133-144.

Kehoe, R. R., \& Wright, P. M. (2013). The impact of high-performance human resource practices on employees' attitudes and behaviors. Journal of management, 39(2), 366-391.

Lacity, M. C., Iyer, V. V., \& Rudramuniyaiah, P. S. (2008). Turnover intentions of Indian IS professionals. Information Systems Frontiers, 10(2), 225-241.

Liu, S., \& Onwuegbuzie, A. J. (2012). Chinese teachers' work stress and their turnover intention. International Journal of Educational Research, 53, 160-170.

Lockwood, N. R. (2007). Leveraging employee engagement for competitive advantage. 2007 SHRM Research Quarterly, 52(3), 1-12.

Malik, M. I., Gomez, S. F., Ahmad, M., \& Saif, M. I. (2010). Examining the relationship of Work Life Balance, Job Satisfaction and Turnover in Pakistan. OIDA International Journal of Sustainable Development, 2(01), 27-33.

Maneesatitya, M., \& Fongsuwan, W. (2014). Structural equation model of variables affecting turnover intentions on bangkok's information technology career professionals. Research Journal of Business Management, 8(4), 453-463.

Mathis, L. R., \& Jackson, H. (2000). Human Resource Management (9th ed.). USA.

Milkovich, G. T., \& Bloom, M. (1998). Rethinking international compensation. Compensation \& Benefits Review, 30(1), 15-23.

Morrow, P., \& McElroy, J. (2007). Efficiency as a mediator in turnover-organizational performance relations. Human Relations, 60(6), $827-849$.

Mudor, P., \& Tooksoon, H. (2011). Conceptual framework on the relationship between human resource management practices, job satisfaction, and turnover. Journal of economic and behaviors studies, 2(2), 41-49.

Murphy, K. S., \& Williams, J. A. (2005). The impact of compensation on the turnover intentions of Outback Steakhouse managers. Journal of Foodservice Business Research, 7(1), 63-80.

Nadiri, H., \& Tanova, C. (2010). An investigation of the role of justice in turnover intentions, job satisfaction, and organizational citizenship behavior in hospitality industry. International Journal of Hospitality Management, 29(1), 33-41.

Nawab, S., \& Bhatti, K. K. (2011). Influence of employee compensation on organizational commitment and job satisfaction: A case study of educational sector of Pakistan. International Journal of Business and Social Science, 2(8), 25-32.

Preacher, K. J., \& Hayes, A. F. (2008). Asymptotic and resampling strategies for assessing and comparing indirect effects in multiple mediator models. Behavior research methods, 40(3), 879-891.

Reinartz, W., Haenlein, M., \& Henseler, J. (2009). An empirical comparison of the efficacy of covariance-based and variance-based SEM. International Journal of research in Marketing, 26(4), 332-344.

Peng, J., Li, D., Zhang, Z., Tian, Y., Miao, D., Xiao, W., \& Zhang, J. (2014). How can core self-evaluations influence job burnout? The key roles of organizational commitment and job satisfaction. Journal of health psychology, In press.

Rubel, M. R. B., \& Kee, D. M. H. (2015). Perceived fairness of performance appraisal, promotion opportunity and nurses turnover intention: The role of organizational commitment. Asian Social Science, 11(9), 183-197. 
Rubel, M. R. B., \& Kee, D. M. H. (2014). Quality of work life and employee performance: Antecedent and outcome of job satisfaction in Partial Least Square (PLS). World Applied Sciences Journal, 31(4), 456-467.

Sarker, M. A. R., \& Afroze, R. (2014). Can HRM practices improve job satisfaction of ready-made garment (RMG) workers in Bangladesh? An alternative solution to recent unrest. International Journal of Business and Management, 9(10), 185-194.

Sekaran, U., \& Bougie, R. (2010). Research methods for business: A skill building approach. London: Wiley

Shamsuzzoha, A., \& Shumon, M. R. H. (2007). Employee turnover- a study of its causes and effects to different industries in Bangladesh. Manufacturing Engineering/ Vyrobne Inzinierstvo, 6(3), 64-68.

Silla, I., \& Gamero, N. (2014). Shared time pressure at work and its health-related outcomes: job satisfaction as a mediator. European Journal of Work and Organizational Psychology, 23(3), 405-418.

Sousa-Poza, A., \& Henneberger, F. (2004). Analyzing job mobility with job turnover intentions: An international comparative study. Journal of Economic Issues, 113-137.

Spagnoli, P., Caetano, A., \& Santos, S. C. (2012). Satisfaction with job aspects: Do patterns change over time? Journal of Business Research, 65(5), 609-616.

Sturman, M. C. (2001). The compensation conundrum: Does the hospitality industry shortchange its employees-and itself? The Cornell Hotel and Restaurant Administration Quarterly, 42(4), 70-76.

Tekleab, A. G., Takeuchi, R., \& Taylor, M. S. (2005). Extending the chain of relationships among organizational justice, social exchange, and employee reactions: The role of contract violations. Academy of Management Journal, 48(1), 146-157.

Vidal, M. E. S., Valle, R. S., \& Aragón, M. I. B. (2007). The adjustment process of Spanish repatriates: A case study. The International Journal of Human Resource Management, 18(8), 1396-1417.

Wang, G. L. (2011). A study of how the internal-service quality of international tourist hotels affects organizational performance: using employees' job satisfaction as the mediator. The Journal of Global Business Management, 7(2), 117-128.

Wang, Y. D., Yang, C., \& Wang, K. Y. (2012). Comparing Public and Private Employees' Job Satisfaction and Turnover. Public Personnel Management, 41(3), 557-573.

Wetzels, M., Odekerken-Schroder, G., \& Van Oppen, C. (2009). Using PLS path modeling for assessing hierarchical construct models: guidelines and empirical illustration. Management Information Systems Quarterly, 33(1), 11.

Whitney, J. L. (1988). Pay Concepts for the 1990s, Part 1. Compensation \& Benefits Review, 20(2), 33-44. 